\title{
Penerapan Model Pembelajaran InKuiri Terbimbing UntUK MeningKatKan Pemahaman KonSEP SiSWa Kelas VII Pada Materi Pengukuran
}

\author{
Herimanto $^{1)}$, Eka Murdani' ${ }^{2)}$, Yudi Kurniawan ${ }^{3)}$ \\ 1) Prodi Pendidikan Fisika STKIP Singkawang \\ E-mail: herimanto091@gmail.com \\ 2) Prodi Pendidikan Fisika STKIP Singkawang \\ E-mail: ekamurdani@gmail.com \\ 3) Prodi Pendidikan Fisika STKIP Singkawang \\ E-mail: yudikurniawan1012@gmail.com
}

\begin{abstract}
Abstrak. Tujuan penelitian ini untuk mendapatkan gambaran peningkatan pemahaman konsep siswa melalui model pembelajaran Inkuiri Terbimbing Jenis penelitian ini adalah kuantitatif dengan rancangan penelitian one group pre-test post-test design. Alat pengukuran dalam penelitian ini test pemahaman konsep berbentuk pilihan ganda, hasil post-test lebih tinggi dari hasil pre-test yaitu dari hasil rata-rata 35,25 menjadi 67,18. Dapat disimpulkan bahwa pemahaman konsep siswa meningkat dengan kategori sedang (Ngain=0,47) setelah diterapkan perlakuan dengan model pembelajaran Inkuiri Terbimbing pada materi pengukuran. Dalam penelitian ini aspek pemahaman konsep yang diukur dibatasi pada aspek; menafsirkan, mencontohkan, menjelaskan, membandingkan, dan mengklasifikasikan. Dari kelima aspek pemahamn konsep yang diukur yang mengalami peningkatan paling tinggi yaitu membandingkan sebesar $80 \%$.
\end{abstract}

Kata Kunci: Inkuiri Terbimbing; Pemahaman Konsep Siswa; Materi Pengukuran

\section{Pendahuluan}

Pembelajaran IPA sebaiknya dilaksanakan secara inkuiri ilmiah (scientific inquiry) untuk menumbuhkan kemampuan berpikir, bekerja dan bersikap ilmiah serta mengkomunikasikannya sebagai aspek penting kecakapan hidup [1] [2]. Sehingga penerapan pembelajaran IPA di SMP/MTs lebih ditekankan pada pemberian pengalaman belajar secara langsung melalui penggunaan dan pengembangan keterampilan proses dan sikap ilmiah. Fisika merupakan bagian dari Ilmu Pengetahuan Alam (sains) yang mencakup produk, proses dan sikap ilmiah [3] [4]. Produk IPA antara lain konsep, hukum, dan teori-teori [5]. Fisika berisi fakta, konsep, dan prinsip yang berdasarkan pada pengamatan tentang fenomena-fenomena tersebut, dan disusun secara sistematis [6] [7]. Dilihat dari hasil prariset yang dilakukan dimana pemahaman siswa tentang soal yang diberikan dimana hampir seluruh siswa tidak bisa menjelaskan sesuai dengan konsep yang sebenarnya. Penelitian ini bertujuan untuk mendapatkan gambaran peningkatan pemahaman konsep siswa setelah diterapakan model pembelajaran Inkuiri Terbimbing dan mendapatkan gambaran respon siswa terhadap model pembelajaran Inkuiri Terbimbing.

Pemahaman konsep terdiri dari dua kata yaitu pemahaman dan konsep. Pemahaman adalah kemampuan seseorang untuk mengerti atau memahami sesuatu setelah sesuatu tersebut diketahui dan diingat [8]. Sedangkan konsep adalah buah pemikiran seseorang atau kelompok orang yang dinyatakan dalam defenisi sehingga melahirkan produk pengetahuan meliputi prinsip, hokum, dan teori [9]. Konsep adalah ide abstrak yang memungkinkan siswa untuk mengelompokkan dan mengklasifikasikan objek/kejadian [10]. Pemahaman konsep merupakan kompetensi yang ditunjukkan siswa dalam memahami konsep dan dalam prosedur yang akurat, efisien dan tepat [11] [12].

Pembelajaran inkuiri terbimbing merupakan pembelajaran yang berpusat pada siswa yang memiliki peran untuk mencari dan menemukan sendiri materi pembelajaran, sedangkan guru berperan sebagai fasilitator untuk mendorong siswa dapat 
menegembangkan disiplin intelektual dan keterampilan berpikir dengan memberikan pertanyaan-pertanyaan [13]. Pembelajaran Inkuiri Terbimbing dimana guru memfasilitasi penyelidikan dan mendorong siswa mengungkapkan atau membuat pertanyaan-pertanyaan yang membimbing mereka untuk penyelidikan lebih lanjut [14]. Inkuiri terbimbing merupakan proses mendefenisikan dan menyelidiki masalahmasalah, merumuskan masalah merumuskan hipotesis, merancang eksperimen, menemukan data dan menggambarkan kesimpulan masalah-masalah tersebut [15].

\section{METODE}

Jenis penelitian ini adalah penelitian kuantitatif, metode yang digunakan pada jenis penelitian ini adalah preexperiment. Pada penelitian ini, metode yang digunakan subjek penelitian pada kelas VII yang berjumlah 32 orang. Subjek ini akan diberikan penerapan Inkuiri Terbimbing untuk melahirkan pemahaman konsep. Instrumen pengumpulan data berupa tes dan non tes. Tes yang dilakukan adalah tes pemahaman konsep dan non tes yang dilakukan berupa tes skala sikap dan lembar observasi.

\section{HASIL DAN PEMBAHASAN}

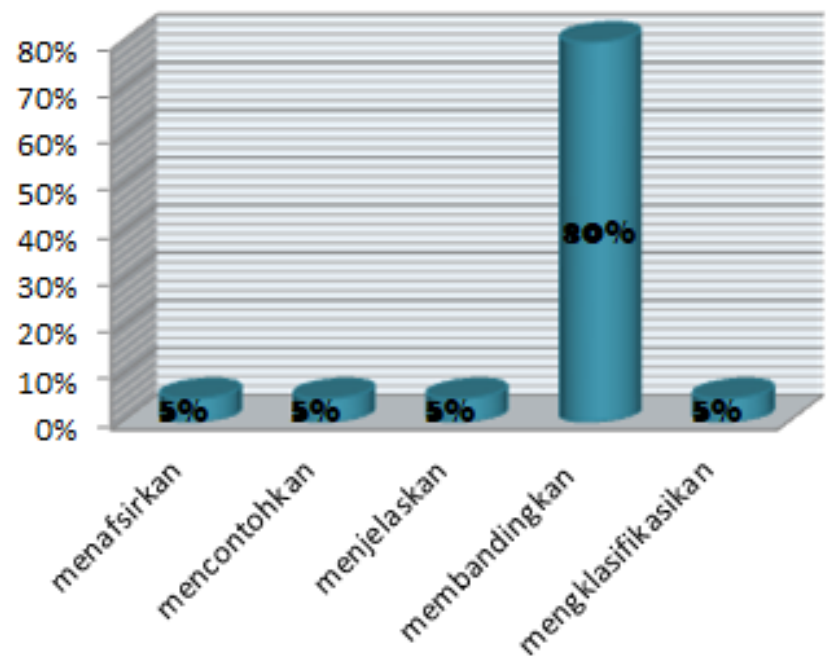

Gambar 1. Grafik rata-rata pemahaman konsep siap tiap indikator

Berdasarkan perhitungan tersebut diungkapkan bahwa ratarata pemahaman konsep siswa setelah dinormalisasikan dengan uji $\mathrm{N}$-gain diperoleh peningkatan nilai sebesar 0,47 , maka hasil belajar ranah kognitif siswa diperoleh peningkatan dengan kategori sedang karena 0,47 berada pada $0,3 \leq \mathrm{N}$-gain $<0,7$.

Analisis data pemahaman konsep siswa, diketahui rata-rata hasil post test lebih tinggi dibandingkan rata-rata hasil pre test. Hal ini dapat dilihat dari perhitungan post test, diperoleh nilai rata-rata post test sebesar 67,18 yang naik sebesar 30,39 (setelah dinormalisasi) dari nilai rata-rata pre test yaitu sebesar 36,25. Untuk pengujian menggunakan $\mathrm{N}$-gain, diketahui pemahaman konsep siswa mengalami peningkatan dengan kategori sedang, yaitu sebesar 0,47. Pada gain ternormalisasi apabila diubah ke dalam kriteria maka pemahaman konsep siswa mengalami peningkatan dengan kriteria sedang. Dalam penelitian ini aspek pemahaman konsep siswa yang mengalami peningkatan, sejalan dengan penelitian yang dilakukan Ayu bahwa penerapan Model Pembelajaran Inkuiri Terbimbibng dapat meningkatkan pemahaman konsep siswa dan Sulistyo menyimpulkan bahwa dengan menerapkan Inkuiri Terbimbing menunjukkan peningkatan keaktifan siswa dan pemahaman konsep siswa [16] [17]. Dibandingkan aspek lain yaitu membandingkan dimana aspek pemahaman konsep ini siswa lebih mudah memahami konsep-konsep yang diberikan sehingga pemahaman konsep siswa meningkat. Pembelajaran menggunakan model pembelajaran Inkuri Terbimbing pada materi pengukuran dinyatakan dapat meningkatkan pemahaman konsep siswa, siswa merespon dengan baik kegiatan pembelajaran [18].

\section{KESIMPULAN}

Aspek yang paling meningkat dalam penelitian ini adalah membandingkan sebesar $80 \%$. Pemahaman konsep siswa mengalami peningkatan sebesar 0,47 dengan kategori sedang setelah diterapkan Model Pembelajaran Inkuiri Terbimbing. Dalam penelitian ini penulis banyak mengalami kendala khususnya pada masalah waktu sehingga proses pembelajaran di dalam kelas ada yang terlewati, disarankan untuk peneliti selanjutnya agar dapat memenajemen waktu dengan baik sehingga dapat melaksakan proses pembelajaran dengan lancar. Sebaiknya model pembelajaran Inkuiri Terbimbing digunakan di sekolah lain, untuk mengetahui pengaruh dan respon siswa di sekolah yang berbeda.

\section{UCAPAN TERIMAKASIH}

Ucapan terima kasih disampaikan kepada STKIP Singkawang yang telah memfasilitasi penulis sehingga tulisan ini dapat dipublikasikan dalam berkala ilmiah STKIP Singkawang "Jurnal Ilmu Pendidikan Fisika".

\section{DAFTAR PUSTAKA}

[1] Permendiknas No 22 tahun 2006. Tentang Standar Isi Pendidikan Dasar dan Menengah. Jakarta

[2] Rosdianto, H. (2017). Students` Conceptual Understanding through Generative Learning Model in Topic "Light". JPI (Jurnal Pendidikan Indonesia), 6(2): 259-262.

[3] Siradjuddin, Rosdianto, H., \& Sulistri, E. (2018) Penerapan Model REACT Untuk Meningkatkan Keterampilan Proses Sains Siswa Pada Materi Arus Listrik. Jurnal Pendidikan Fisika dan Keilmuan (JPFK), 4(1): 17-22.

[4] Irhamna, Rosdianto, H., \& Murdani, E. (2017). Penerapan Model Learning Cycle 5E untuk Meningkatkan Keterampilan Berpikir Kritis Siswa Pada Materi Fluida Statis Kelas VIII. Jurnal Fisika Flux, 14(1): 61-64.

[5] Nadiya, Rosdianto, H., \& Murdani, E. (2016). Penerapan Model Pembelajaran Group Investigation (GI) untuk 
Meningkatkan Keterampilan Berpikir Kritis Siswa pada Materi Gerak Lurus Kelas X. JIPF (Jurnal Ilmu Pendidikan Fisika), 1(2): 49-51.

[6] Ihsanudin, M. (2014). Manfaat Teknologi Informasi dalam Pendidikan Fisika. Jurnal Pendidikan Inovatif, 2(1).

[7] Rosdianto, H. (2017). Pengaruh Model Generative Learning Terhadap Hasil Belajar Ranah Kognitif Siswa Pada Materi Hukum Newton. Jurnal Pendidikan Fisika dan Keilmuan (JPFK), 3(2), 66-69.

[8] Nurfarikhin. (2010). Konsep Dan Makna Pembelajaran. Bandung: Alfabeta

[9] Sagala, Syaiful (2010). Konsep dan Makna Pembelajaran.Jakarta: Alfabeta

[10] Wardani. (2010). Konsep dan Makna Pembelajaran. Jakarta : Graha Ilmu

[11] Shadiq. (2009). Makna Pembelajaran. Yogyakarta: Alfabeta

[12] Rosdianto, H., Murdani, E., \& Hendra. (2017). The Implementation of POE (Predict Observe Explain) Model to Improve Student's Concept Understanding on Newton's Law. Jurnal Pendidikan Fisika, 6(1): 55-57.

[13] Suyanti, R.D.(2010). Strategi Pembelajaran Kimia. Yogyakarta: Graha Ilmu

[14] Suparno, P. (2007). Metodologi Pembelajaran Fisika Konstruktivistik \& Menyenangkan. Yogyakarta: Universitas Sanata Darma

[15] Asri. (2007). Belajar dan Pembelajaran. Jakarta: Rineka Cipta

[16] Ayu. (2009). Penerapan Model Pembelajaran Inkuiri Terbimbing Dapat Meningkatkan Pemahaman Konsep Siswa Siswa. Semarang: Universitas Negeri Semarang

[17] Sulistyo. (2006). Penerapan Inkuiri Terbimbing Untuk Meningkatkan Aktivitas Siswa. Bandung: Universitas Padjajaran Bandung

[18] Herniati, R., Sulistri, E., \& Rosdianto, H. (2017). Penerapan Model Predict Observe Explain Dengan Pendekatan Learning by Doing Untuk Meningkatkan Hasil Belajar Siswa. Jurnal Fisika FLUX, 14(2): 120124. 